\title{
Usefulness of endoscopic ultrasound-guided fine needle aspiration for splenic parenchyma in patients suspected of having primary splenic malignant lymphoma
}

\section{(ㄷ)(1) $(-)$}

\author{
Authors \\ Institutions \\ 1 Division of Gastroenterology, Department of Internal \\ Medicine, Showa University Fujigaoka Hospital, \\ Yokohama, Kanagawa, Japan \\ 2 Department of Hematology, Department of Internal \\ Medicine, Showa University Fujigaoka Hospital, \\ Yokohama, Kanagawa, Japan \\ 3 Department of Diagnostic Pathology, Showa University \\ Fujigaoka Hospital, Yokohama, Kanagawa Japan
}

Fumitaka Niiya', Yuichi Takano', Tetsushi Azami ${ }^{1}$, Takahiro Kobayashi' ${ }^{1}$, Naotaka Maruoka ${ }^{1}$, Nobuyuki Kabasawa², Hiroshi Harada², Tomoko Norose ${ }^{3}$, Nobuyuki Ohike ${ }^{3}$, Masatsugu Nagahama ${ }^{1}$

submitted 2.6.2020

accepted after revision 18.8 .2020

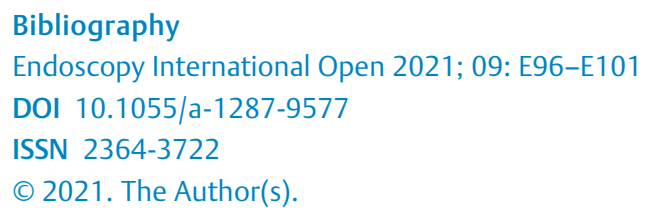

Corresponding author

Fumitaka Niiya, Division of Gastroenterology, Department of Internal Medicine, Showa University Fujigaoka Hospital, 1-30 Fujigaoka, Aoba-ku, Yokohama-shi, Kanagawa 2278501, Japan

Fax: +81-45-9731019

spice_up_yourlife_10_4@yahoo.co.jp

\section{ABSTRACT}

Background and study aims The diagnosis of malignant lymphoma (ML) is sometimes difficult, especially in patients with primary splenic malignant lymphomas (psML) which have no lymph nodes capable of acting as the biopsy target. We carried out endoscopic ultrasound-guided fine needle aspiration (EUS-FNA) for "splenic parenchyma" in patients suspected of having a psML, even without any obvious neoplastic lesions in the spleen.

Patients and methods A retrospective study using medical records was conducted of eight patients suspected of having a psML that received EUS-FNA for the splenic parenchyma between January 2016 and January 2019. Data analyzed included clinical background, EUS-FNA procedure (puncture needle/route), diagnostic ability (pathological/ flow cytometry [FCM]), and complications.

Results EUS-FNA was performed from the stomach in all eight cases, and no patients had complications. As a result of splenic parenchymal biopsy found on EUS-FNA, 75\% of patients (6/8) were histologically diagnosed with MLs, monoclonality of B-cells was identified in all cases (8/8) with FCM, and all patients (8/8) were definitively diagnosed with psMLs.

Conclusion EUS-FNA for "splenic parenchyma" is useful for patients with spML, even if they have no obvious neoplastic lesions in the spleen.

\section{Introduction}

Malignant lymphoma (ML) is a neoplastic lesion in lymphoid cells and may be fatal. Treatment for ML has dramatically advanced in recent years, with a number of effective chemotherapies reported [1]. In many cases, ML is diagnosed via a biopsy of swollen lymph nodes found all over the body. However, primary splenic malignant lymphomas (psML) have lesions localized in the spleen, with no lymph nodes capable of acting as the biopsy target. These characteristics make diagnosis difficult.

Our hospital carries out endoscopic ultrasound-guided fine needle aspiration (EUS-FNA) for "splenic parenchyma" together with the Department of Hematology in patients suspected of having a psML, even without any obvious neoplastic lesions in the spleen. There have been no studies of EUS-FNA for"splenic parenchyma" in patients with psM. We evaluated the usefulness and safety thereof. 


\section{Patients and methods}

A retrospective study using medical records was conducted of eight patients suspected of having a psML without any neoplastic lesion in spleen that received EUS-FNA for the splenic parenchyma between January 2016 and January 2019.

The data assessed were clinical background, procedure of EUS-FNA (puncture needle/route), diagnostic ability (pathological/flow cytometry [FCM]), complications, treatment, and number of days to diagnosis (from the date of sample collection to the first report of diagnosis). We also examined the presence/absence of bone marrow infiltration based on a bone marrow biopsy (pathological/FCM).

The diagnosis of psML was made using the definition by Guputa [2]. That is, psML must meet all four of the following criteria: (1) splenomegaly present with symptoms; (2) lesions at other sites can be ruled out; (3) no ML in other lymph nodes is found at the time of abdominal operation; and (4) no lesions at other sites are found for more than 6 months from the diagnosis of ML. MLs were classified according to the WHO criteria (2017) [3].

In this study, there were no cases in which the liver was punctured

\section{EUS-FNA procedure}

EUS-FNA was performed under sedation (midazolam 2-5 mg and pentazocine $7.5 \mathrm{mg}$ ). The instrument used was a convextype ultrasonic endoscope GF-UCT260 (Olympus Medical Systems Corp, Tokyo, Japan) and the observation device was UEME1 or ME-ME2 (Olympus). The puncture was carried out with a 22G or 25G G needle (Expect SlimLine, Boston Scientific Japan, Tokyo, Japan). The puncture procedure was 20 strokes under a negative pressure of $20 \mathrm{~mL}$ or a slow-pull method, and puncture was performed twice. Puncture was performed by the fanning technique as much as possible to obtain a wide range of tissue. For puncturing, we used Doppler to evaluate the blood flow and avoid the splenic hilum, puncturing from the upper or lower pole. Elastography was not performed in all cases.

Before puncturing, we measured coagulation and platelets by taking blood samples from all patients to assess the risk of bleeding and validate the hemostatic function. Oral administration of the anticoagulant/antiplatelet agent was discontinued for examination in accordance with the Japanese Gastrointestinal Endoscopy Society (JGES) guidelines [4].

Twenty-four hours after biopsy, a medical examination and blood testing were carried out to evaluate for anemia and inflammation.

The definition of adverse events (AEs) from the workshop of the American Society of Gastrointestinal Endoscopy (ASGE) was used [5].

\section{Histopathological testing and immunological and morphological diagnosis}

The obtained specimens were extruded onto a plate using a stylet or Hank's solution. We made a histological diagnosis of the solid components after formalin fixation and made a cytodiagnosis of the solution components after dissolution using Hank's solution. Our hospital does not perform ROSE (rapid on-site evaluation).

For immunohistochemical staining, L26 (CD20) and CD79a were used for the B-cell line marker, while CD3 and CD5 were used for the T-cell line marker. In addition, CD4, CD8, CD10, CD30, CD56, bcl2, bcl6, MUM-1, cyckinD1, and ki-67 were added as appropriate.

We submitted the cytodiagnosis and histological diagnosis of the obtained specimens, conducting a marker search on the cell surface with multiparameter flow cytometry (MFCM).

- Table 1 Clinical background and endoscopic ultrasound-guided fine-needle aspiration (EUS-FNA) procedure in the cases.

\begin{tabular}{|c|c|c|c|c|c|c|c|}
\hline $\begin{array}{l}\mathrm{Pa}- \\
\text { tient }\end{array}$ & $\begin{array}{l}\text { Age/ } \\
\text { sex }\end{array}$ & Symptom & Final diagnosis & $\begin{array}{l}\text { EUS-FNA } \\
\text { diagnosis }\end{array}$ & $\begin{array}{l}\text { Puncture } \\
\text { needle gauge }\end{array}$ & $\begin{array}{l}\text { EUS-FNA com- } \\
\text { plications }\end{array}$ & Treatment \\
\hline 1 & $68 / \mathrm{F}$ & Pancytopenia & $\begin{array}{l}\text { Low-grade B-cell } \\
\text { lymphoma }\end{array}$ & $\begin{array}{l}\text { Low-grade B-cell } \\
\text { lymphoma }\end{array}$ & 22 & none & Chemotherapy \\
\hline 2 & $69 / M$ & Pancytopenia & DLBCL & DLBCL & 22 & none & Chemotherapy \\
\hline 3 & $77 / \mathrm{M}$ & $\begin{array}{l}\text { Leukocyte } \\
\text { elevation }\end{array}$ & $\begin{array}{l}\text { Low-grade B-cell } \\
\text { lymphoma }\end{array}$ & $\begin{array}{l}\text { Low-grade B-cell } \\
\text { lymphoma }\end{array}$ & 22 & none & Chemotherapy \\
\hline 4 & $51 / F$ & Fever & $\begin{array}{l}\text { Low-grade B-cell } \\
\text { lymphoma }\end{array}$ & $\begin{array}{l}\text { Low-grade B-cell } \\
\text { lymphoma }\end{array}$ & 22 & none & Chemotherapy \\
\hline 5 & $79 / M$ & Fever & B-cell lymphoma & Bcell Lymphoma & 25 & none & Chemotherapy \\
\hline 6 & $66 / M$ & Anemia & $\begin{array}{l}\text { Low-grade B-cell } \\
\text { lymphoma }\end{array}$ & $\begin{array}{l}\text { Low-grade B-cell } \\
\text { lymphoma }\end{array}$ & 22 & none & Chemotherapy \\
\hline 7 & $70 / \mathrm{M}$ & $\begin{array}{l}\text { Thrombocyto- } \\
\text { penia }\end{array}$ & $\begin{array}{l}\text { Low-grade B-cell } \\
\text { lymphoma }\end{array}$ & $\begin{array}{l}\text { Low-grade B-cell } \\
\text { lymphoma }\end{array}$ & 25 & none & Chemotherapy \\
\hline 8 & $55 / M$ & anemia & B-cell lymphoma & B-cell lymphoma & 25 & none & Chemotherapy \\
\hline
\end{tabular}



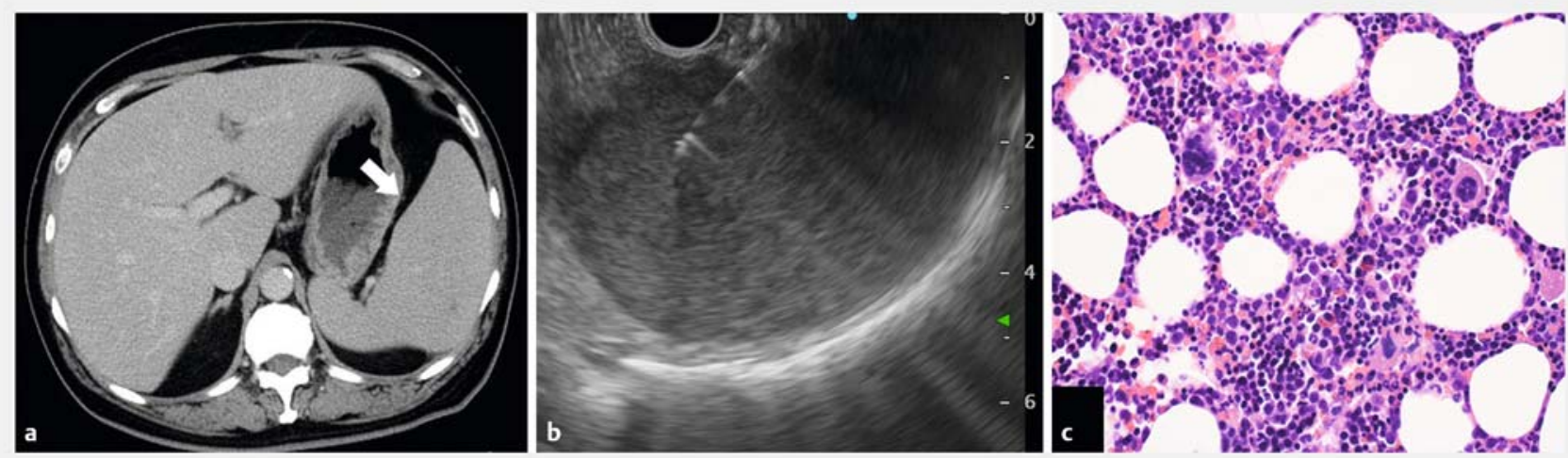

- Fig. 1 A 69-year-old man with thrombocytopenia accompanied by fever and weight loss and was referred to the Hematology Department for suspected malignant lymphoma (Case 2 in the tables). a Computed tomography shows marked splenomegaly. However, there is no enlarged lymph nodes in the body nor is there an obvious neoplastic lesion in the spleen. Primary splenic malignant lymphoma was suspected. b Endoscopic ultrasound-guided fine-needle aspiration (EUS-FNA) was carried out on the splenic parenchyma. c Histology of bone marrow biopsy shows three types of hematopoietic cells, but no clear blastic cell proliferation.
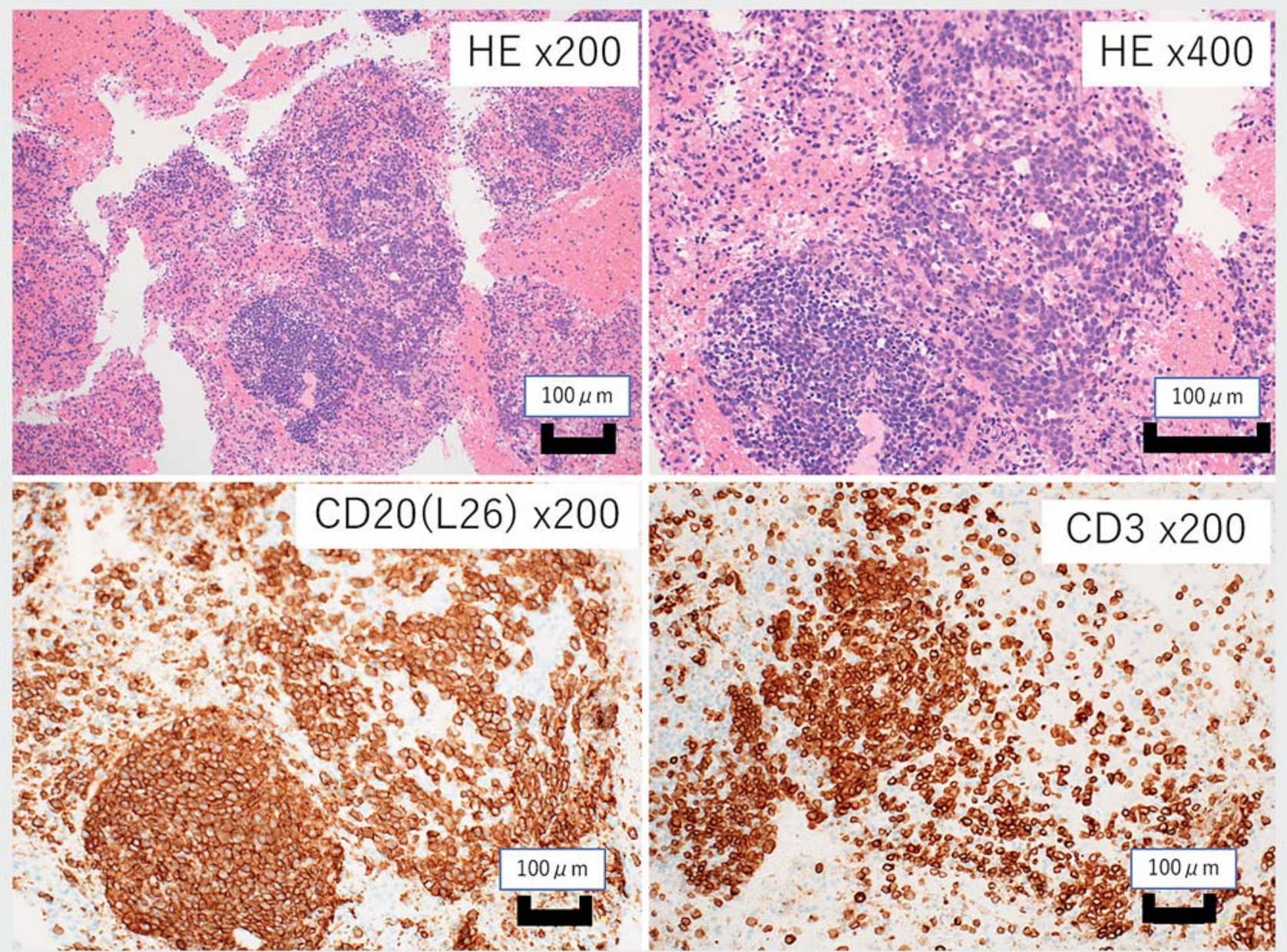

- Fig. 2 Histology of EUS-FNA shows atypical lymphoid cells with relatively large nuclei were found to aggregate (Case 2 in the tables). These cells were positive for expression of CD20 on immunohistological staining. The patient was finally diagnosed with primary splenic malignant lymphoma (diffuse large B-cell lymphoma). 
- Table2 Comparison of bone marrow biopsy and spleen parenchyma biopsy with endoscopic ultrasound-guided fine-needle aspiration (EUS-FNA).

\begin{tabular}{|c|c|c|c|c|c|c|c|c|}
\hline \multirow[b]{2}{*}{$\begin{array}{l}\mathrm{Pa}- \\
\text { tient }\end{array}$} & \multirow{2}{*}{$\begin{array}{l}\text { Final } \\
\text { diagnosis }\end{array}$} & \multicolumn{3}{|c|}{ Bone marrow biopsy } & \multicolumn{4}{|c|}{ EUS-FNA for spleen parenchyma } \\
\hline & & $\begin{array}{l}\text { Final diagno- } \\
\text { sis }\end{array}$ & $\begin{array}{l}\text { Pathological } \\
\text { diagnosis }\end{array}$ & $\begin{array}{l}\text { Flow cyto- } \\
\text { metry }\end{array}$ & $\begin{array}{l}\text { Final diagno- } \\
\text { sis }\end{array}$ & $\begin{array}{l}\text { Pathological } \\
\text { diagnosis }\end{array}$ & FCM & $\begin{array}{l}\text { Time to } \\
\text { diagnosis } \\
\text { (days) }\end{array}$ \\
\hline 1 & $\begin{array}{l}\text { Low-grade } \\
\text { B-cell lym- } \\
\text { phoma }\end{array}$ & $\begin{array}{l}\text { Non-diagnos- } \\
\text { tic }\end{array}$ & $\begin{array}{l}\text { Non-diagnos- } \\
\text { tic }\end{array}$ & $\begin{array}{l}\text { Non-diag- } \\
\text { nostic }\end{array}$ & $\begin{array}{l}\text { Low-grade } \\
\text { B-cell lym- } \\
\text { phoma }\end{array}$ & $\begin{array}{l}\text { Non-diagnos- } \\
\text { tic }\end{array}$ & $\begin{array}{l}\text { Monoclo- } \\
\text { nal B-cell }\end{array}$ & 4 \\
\hline 2 & DLBCL & $\begin{array}{l}\text { Non-diagnos- } \\
\text { tic }\end{array}$ & $\begin{array}{l}\text { Non-diagnos- } \\
\text { tic }\end{array}$ & $\begin{array}{l}\text { Non-diag- } \\
\text { nostic }\end{array}$ & DLBCL & DLBCL & $\begin{array}{l}\text { Monoclo- } \\
\text { nal B-cell }\end{array}$ & 5 \\
\hline 3 & $\begin{array}{l}\text { Low-grade } \\
\text { B-cell lym- } \\
\text { phoma }\end{array}$ & $\begin{array}{l}\text { B-cell lym- } \\
\text { phoma }\end{array}$ & $\begin{array}{l}\text { Non-diagnos- } \\
\text { tic }\end{array}$ & $\begin{array}{l}\text { Monoclo- } \\
\text { nal B-cell }\end{array}$ & $\begin{array}{l}\text { Low-grade } \\
\text { B-cell lym- } \\
\text { phoma }\end{array}$ & $\begin{array}{l}\text { Low-grade B- } \\
\text { cell lympho- } \\
\text { ma }\end{array}$ & $\begin{array}{l}\text { Monoclo- } \\
\text { nal B-cell }\end{array}$ & 3 \\
\hline 4 & $\begin{array}{l}\text { Low-grade } \\
\text { B-cell lym- } \\
\text { phoma }\end{array}$ & $\begin{array}{l}\text { Follicular } \\
\text { B-cell lym- } \\
\text { phoma }\end{array}$ & $\begin{array}{l}\text { Follicular } \\
\text { B-cell lym- } \\
\text { phoma }\end{array}$ & $\begin{array}{l}\text { Monoclo- } \\
\text { nal B-cell }\end{array}$ & $\begin{array}{l}\text { Low-grade } \\
\text { B-cell lym- } \\
\text { phoma }\end{array}$ & $\begin{array}{l}\text { Non-diagnos- } \\
\text { tic }\end{array}$ & $\begin{array}{l}\text { Monoclo- } \\
\text { nal B-cell }\end{array}$ & 5 \\
\hline 5 & $\begin{array}{l}\text { B-cell lym- } \\
\text { phoma }\end{array}$ & $\begin{array}{l}\text { Non-diagnos- } \\
\text { tic }\end{array}$ & $\begin{array}{l}\text { Non-diagnos- } \\
\text { tic }\end{array}$ & $\begin{array}{l}\text { Non-diag- } \\
\text { nostic }\end{array}$ & $\begin{array}{l}\text { B-cell lym- } \\
\text { phoma }\end{array}$ & $\begin{array}{l}\text { B-cell lym- } \\
\text { phoma }\end{array}$ & $\begin{array}{l}\text { Monoclo- } \\
\text { nal B-cell }\end{array}$ & 6 \\
\hline 6 & $\begin{array}{l}\text { Low-grade } \\
\text { B-cell lym- } \\
\text { phoma }\end{array}$ & $\begin{array}{l}\text { Low-grade } \\
\text { B-cell lym- } \\
\text { phoma }\end{array}$ & $\begin{array}{l}\text { Low-grade } \\
\text { B-cell lym- } \\
\text { phoma }\end{array}$ & $\begin{array}{l}\text { Monoclo- } \\
\text { nal B-cell }\end{array}$ & $\begin{array}{l}\text { Low-grade } \\
\text { B-cell lym- } \\
\text { phoma }\end{array}$ & $\begin{array}{l}\text { Low-grade } \\
\text { B-cell lym- } \\
\text { phoma }\end{array}$ & $\begin{array}{l}\text { Monoclo- } \\
\text { nal B-cell }\end{array}$ & 6 \\
\hline 7 & $\begin{array}{l}\text { Low-grade } \\
\text { B-cell lym- } \\
\text { phoma }\end{array}$ & $\begin{array}{l}\text { Low-grade } \\
\text { B-cell lym- } \\
\text { phoma }\end{array}$ & $\begin{array}{l}\text { Non-diagnos- } \\
\text { tic }\end{array}$ & $\begin{array}{l}\text { Monoclo- } \\
\text { nal B-cell }\end{array}$ & $\begin{array}{l}\text { Low-grade } \\
\text { B-cell lym- } \\
\text { phoma }\end{array}$ & $\begin{array}{l}\text { Low-grade } \\
\text { B-cell lym- } \\
\text { phoma }\end{array}$ & $\begin{array}{l}\text { Monoclo- } \\
\text { nal B-cell }\end{array}$ & 4 \\
\hline 8 & $\begin{array}{l}\text { B-cell lym- } \\
\text { phoma }\end{array}$ & $\begin{array}{l}\text { B-cell lym- } \\
\text { phoma }\end{array}$ & $\begin{array}{l}\text { B- cell lym- } \\
\text { phoma }\end{array}$ & $\begin{array}{l}\text { Monoclo- } \\
\text { nal B-cell }\end{array}$ & $\begin{array}{l}\text { B-cell lym- } \\
\text { phoma }\end{array}$ & $\begin{array}{l}\text { B-cell lym- } \\
\text { phoma }\end{array}$ & $\begin{array}{l}\text { Monoclo- } \\
\text { nal B-cell }\end{array}$ & 5 \\
\hline
\end{tabular}

EUS-FNA, endoscopic ultrasound-guided fine-needle aspiration; FCM, flow cytometry; DLBCL, diffuse large B-cell lymphoma.

\section{Results}

Information on the eight patients that underwent splenic parenchyma biopsy with EUS-FNA is shown in $>$ Table 1.

The median age of subjects was 68.5 (age 51-79), including six males and two females. Regarding the clinical symptoms, there were five cases with B symptoms (fever, weight loss, and night sweats) and six cases with blood cell abnormalities (2 cases of pancytopenia, 1 case of thrombocytopenia, 1 case of leukocytosis, and 2 cases of anemia). All patients had splenomegaly.

EUS-FNA was performed from the stomach in all cases. No patients had complications (bleeding/abdominal pain/pneumothorax/fever, etc.). The spleen was swollen in all cases, but the internal echo was a uniform hypoecho, and there was no difference from the normal spleen. Tissue specimens were collected from all patients. A $22 \mathrm{G}$ puncture needle was used in five cases and a $25 \mathrm{G}$ puncture needle was used in three cases.

As a result of splenic parenchymal biopsy by EUS-FNA, 75\% of patients (6/8) were histologically diagnosed with MLs, monoclonality of B-cells was identified in all cases (8/8) by FCM, and all patients $(8 / 8)$ were definitively diagnosed with MLs. The median time to reach a diagnosis was 5 days (3-6) (> Fig. 1, - Fig. 2, and $>$ Table 2).
Regarding the histological type, there were seven cases of Bcell lymphoma and one case of diffuse large B-cell lymphoma (DLBCL). There were five cases of stage IV and three cases of stage I disease. All patients underwent chemotherapy.

A bone biopsy was carried out in all patients. Bone marrow infiltration of the ML was histologically found in $33 \%$ of patients (3/8), monoclonality of B-cells was identified in $62.5 \%$ of patients $(5 / 8)$ by FCM, and $62.5 \%$ of patients $(5 / 8)$ were definitively diagnosed with bone marrow infiltration by ML ( $>$ Table 2).

\section{Discussion}

In this study, we performed EUS-FNA for "splenic parenchyma" in patients suspected of having a psML, even without any obvious neoplastic lesions in the spleen. Diagnosis of malignant lymphoma was obtained in all cases, and in less time than with bone marrow biopsy.

As the histological type determines the prognosis and chemotherapy regimen for MLs, definitive diagnosis is essential. In many cases, a diagnosis can be made based on a biopsy of the enlarged lymph nodes. However, the characteristic that the psML has no target lymph nodes makes diagnoses difficult.

According to Kehoe et al. [6], the prognosis for psML is extremely poor, with a 5 -year survival rate of $43 \%$ in stage $1 /$ II 
and a 5 -year survival rate of $14 \%$ in stage III according to the Ahmann classification [7].

A splenectomy or biopsy under ultrasound computed tomography (CT) guidance has been performed in patients suspected of having a psML. However, these tissue sampling methods are said to involve more complications, such as bleeding and perforations.

Civardi et al. reported that the incidence of complications arising from image-guided spleen biopsies was 5.2\%, among which the incidence of severe complications was $0.75 \%$ [8]. Mclnnes et al. reported that the incidence of severe complications due to a CT-guided spleen biopsy or percutaneous ultrasound spleen biopsy using an $18 \mathrm{G}$ needle was $2.2 \%$ [9]. It may be difficult to observe adjacent organs and blood vessels in CTand ultrasound-guided biopsies, so the incidence of complications may be relatively high.

With regard to splenectomy, Han et al. examined 59 cases and reported that the diagnostic performance was not sufficient, with a sensitivity of $72.2 \%$, and the incidence of complications was high (25.9\%) [10].

EUS-FNA was first reported in 1992 as a biopsy method for pancreatic tumors by Vilmann et al [11]. Thereafter, the indication for procedure has been expanded to general lesions, significantly contributing to diagnosis and treatment. EUS-FNA allows safe puncture into pancreatic tumors, hepatic tumors, and mediastinal/intraabdominal lymph nodes, which is useful for diagnosis [12]. EUS also enables closer observation of the spleen compared with percutaneous methods, with a high spatial resolution that facilitates easy recognition of small intervening vessels.

The most concerning complication is bleeding from the spleen. Because it present as intra-abdominal rather than gastrointestinal bleeding, it cannot be properly assessed without image diagnosis such as CT. In this study, CT was not routinely performed after EUS-FNA, so a small amount of intra-abdominal bleeding may have occurred. On the other hand, postoperative blood tests showed no cases of progression of anemia. If postoperative anemia progresses or abnormal vital signs (tachycardia or hypotension) were observed, CT should be performed promptly.

Although splenic tumors are relatively rare, in recent years, several studies have reported on the diagnosis of malignant lymphomas "with neoplastic lesions in the spleen" revealed by EUS-FNA.

We found 42 cases in PubMed from 2003 to 2018 in which patients underwent EUS-FNA for splenic tumors. Among them, we examined nine cases with a diagnosis of ML [13-18]. The median age of subjects was 60 (age 41-83), including five males and four females. Five cases used a $22 \mathrm{G}$ puncture needle, two cases 19G, one case 25G, and in one case the needle size was unknown. All procedures were successful, and no complications were observed.

The final diagnosis was two cases of Hodgkin lymphoma and seven cases of non-Hodgkin lymphoma, among which the subtypes of five cases were identifiable ( 3 cases of DLBCL and 2 cases of follicular lymphoma). Seven patients underwent flow cytometry, with monoclonal B-cells found in two cases, and it was reportedly useful in five cases.

It is obvious that EUS-FNA is useful for ML with tumors in the spleen. However, there have been no studies of EUS-FNA for "splenic parenchyma" in cases with ML without obvious neoplastic lesions in the spleen.

In this study, we performed a "splenic parenchyma" biopsy using EUS-FNA in eight cases with psML. All of the procedures were successful and no complications were observed.

The diameter of the puncture needle (22G or 25G) was determined by the endoscopist. In this study, there was no difference in the diagnostic ability depending on the diameter of the puncture needle, and diagnosis was possible in all cases. Although a thick puncture needle can obtain sufficient tissue, complications are a concern. Because the spleen has abundant blood flow, there is a risk of bleeding due to biopsy. Therefore, a biopsy with a 22G or 25G needle was performed. Because this study had a small number of cases, a large number of cases must be examined to determine the appropriate puncture needle diameter for spleen biopsy.

The combination of FCM and pathological evaluation leads to diagnoses of psML in all cases within a short time (5 days, average). We believe that early diagnosis was possible because it did not require the process of decalcification for specimen preparation as required in bone biopsies.

Patients without bone marrow infiltration accounted for $37.5 \%$ of cases in this study. In such cases, a bone biopsy alone could not lead to a definite diagnosis. Because psML often do not involve bone marrow infiltration, a spleen biopsy is considered to be extremely useful.

In combination with histological diagnosis, analysis of markers on the cell surface using FCM and chromosomal analysis is said to be vital in the diagnosis of ML. According to Yasuda et al. [19], EUS-FNA in 104 cases of lymphadenopathy of unknown origin, in combination with histological diagnosis and cell diagnosis and cell surface marker analysis using FCM and chromosomal analysis, led to an accurate diagnosis rate of $98 \%$.

This study also showed the usefulness of FCM, where the combined use of FCM demonstrated that the monoclonality of proliferated lymphocytes lead to diagnoses of ML in patients who were not pathologically diagnosed with ML.

We investigated the usefulness of "splenic parenchyma" biopsies under EUS-FNA for psML. The procedures could be performed safely with a high diagnostic yield and enabled a diagnosis within a short period of time. Going forward, we believe further study is necessary with a larger number of subjects as opposed to the small number of subjects in this study.

The limitations of this study are that it was single-center, small, and retrospective. In the future, it is expected that the utility of spleen biopsy for malignant lymphoma will be clarified by conducting a large number of multicenter studies.

\section{Conclusions}

EUS-FNA for "splenic parenchyma" is considered to be useful for evaluating patients with spML, even if they have no obvious neoplastic lesions in the spleen. 


\section{Competing interests}

The authors declare that they have no conflict of interest.

References

[1] Alduaij W, Ivanov A, Honeychurch J et al. Novel type II anti-CD20 monoclonal antibody (GA101) evokes homotypic adhesion and actindependent, lysosome mediated cell death in B-cell malignancies. Blood 2011; 117: 4519-4529

[2] Guputa TD, Coombes B, Brasfield RD. Primary malignant neoplasms of the spleen. Surg Gynecol Obstet 1965; 120: 647-960

[3] Swerdlow SH, Campo E, Harris NL et al. WHO Classification of Tumours of Haematopoietic and Lymphoid Tissues. Lyon, France: IARC; 2017

[4] Fujimoto K, Fujishiro M, Kato M et al. Guidelines for gastroenterological in patients undergoing antithrombotic trearment. Dig Endosc 2014; 26: 1-14

[5] Cotton PB, Eisen GM, Aabakken L et al. A lexicon for endoscopic adverse events: report of an ASGE workshop. Gastrointest Endosc 2010; 71: 446-454

[6] Kehoe J, Straus DJ. Primary Lymphoma of the spleen. Surg Today 1992; 22: 371-375

[7] Ahmann DL, Keily JM, Harrison EG et al. Malignant lymphoma of the spleen: A review of 49 cases in which the diagnosis was made at splenectomy. Cancer 1966; 19: 461-469

[8] Civardi G, Vallisa D, Bert'e R et al. Ultrasound-guided fine needle biopsy of the spleen: high clinical efficacy and low risk in a multicenter Italian study. Am J Hematol 2001; 67: 93-99

[9] McInnes MDF, Kielar AZ, Macdonald DB. Percutaneous image-guided biopsy of the spleen: systematic review and meta-analysis of the complication rate and diagnostic accuracy. Radiology 2011; 260: 699-708

[10] Han B, Yang Z, Yang T et al. Diagnostic splenectomy in patients with fever of unknown origin and splenomegaly. Acta Haematol 2008; 119: $83-88$

[11] Vilmann P, Jacobson GK, Henriksen FW et al. Endosonography guided with fine needle aspiration biopsy in pancreatic disease. Gastrointest Endosc 1992; 38: 172-173

[12] Eloubeidi MA, Chen VK, Eltoum IA et al. Endoscopic ultrasound-guided fine needle aspiration biopsy of patients with suspected pancreatic cancer: diagnostic accuracy and acute and 30-day complications. Am J Gastroenterol 2003; 98: 2663-2668

[13] Fritscher-Ravens A, Mylonaki M, Pantes A et al. Endoscopic ultrasound-guided biopsy for the diagnosis of focal lesions of the spleen. Am J Gastroenterol 2003; 98: 1022-1027

[14] Iwashita T, Yasuda I, Tsurumi H et al. Endoscopic ultrasound-guided fine needle aspiration biopsy for splenic tumor: a case series. Endoscopy 2009; 41: 179-182

[15] Eloubeidi MA, Varadarajulu S, Eltoum IA et al. Transgastric endoscopic ultrasound-guided fine-needle aspiration biopsy and flow cytometry of suspected lymphoma of the spleen. Endoscopy 2006; 38: 617-620

[16] Majzoub NE, Kharfan-Dabaja MA, Boulos Fl et al. Diagnosing diffuse large B-cell non-hodgkin lymphoma by endoscopic ultrasound-fineneedle aspiration of a splenic mass. J Clin Oncol 2013; 31: 223-225

[17] El Hajj II, Khalid A, Schoedel KE et al. EUS-guided FNA diagnosis of primary splenic lymphoma. Gastrointest Endosc 2009; 69: 585-588

[18] Darr U, Khan Z, Khan MA et al. Diagnosis of splenic lymphoma by endoscopic ultrasound guided fine needle aspiration: a case report and review of the literature. Case Rep Gastrointest Med 2017; 2017: $36-2910$

[19] Yasuda I, Turumi H, Omar S et al. Endoscopic ultrasound-guided fineneedle aspiration biopsy for lymphadenopathy of unknown origin. Endoscopy 2006; 38: 919-924 